\title{
A Methodology to Diagnose ICT Governance Process Based on ISO/IEC 38500 Standard. Case Study: Ecuadorian Retail Organization
}

\author{
Andrés Robalino-López \\ Grupo de Investigación de Sistemas de \\ Información, Gestión de la Tecnología \\ e Innovación. Departamento de \\ Estudios Organizacionales y Desarrollo \\ Humano,Escuela Politécnica Nacional \\ Quito-Ecuador \\ andres.robalino@epn.edu.ec
}

\author{
Daniel Real \\ Escuela Politécnica Nacional \\ Quito-Ecuador \\ daniel.real@epn.edu.ec
}

\author{
Zanna Aniscenko \\ University of Seville) \\ Seville-Spain \\ zanna.aniscenko@gmail.com
}

\begin{abstract}
The purpose of this paper is to show the application of a new methodology approach to diagnose the impact of management of Information and Communication Technologies (ICT) with the reference frame ISO/IEC 38500 inside the organizations. It is based on the government's analysis of organization's technological resource management, being the strategic axis part of business strategic planning and its ICT Governance, effectiveness and efficiency, and the value of ICT for its guidelines and the risks involved in its development to optimize the use of organization's resources. In the first stage, a documentary research was carried out as an essential part of this study and an interview with an expert; Then a tool (questionnaire) was designed to collect, measure and evaluate data on aspects and components of the ISO/IEC 38500 standard. A case study of Ecuadorian retail organization was carried out. Once the information was processed, the respective indicators were obtained that helped to identify current status of ICT governance processes of the organization. With the obtained indicators we could see which principles are the ones that characterize this sector, in which they put the greatest amount of resources; be they human or financial. It was also evident that the two dimensions on which the study was based on have very different results, since emphasis was placed on what corresponds.
\end{abstract}

Keywords-ISO/IEC 38500, ICT Government, Methodology Approach, Retail Sector.

\section{INTRODUCTION}

The use of Information and Communication Technologies (ICT's) has become as one more phenomenon within globalization; stimulating the starting point for the optimization of managerial processes and causing changes in the organizational structure. The importance and influence of ICT's in an organization are directly linked to the characteristics of it, so ICT's will differ from a size of an organization whether it is a small and medium enterprise (SME) or a large organization.

Currently, more companies make important investments in information and communication technologies in order to meet specific needs, such as growth of the organization, seeking for greater control in their transactions, information storage and processing, etc. However, many of them do not see immediate benefits from such high investments, mainly due to the inefficient use of ICT's due to inadequate implementation or use of it.

Thus, the introduction of ICT's in companies has advantages, however it also imposes risks; this last scenario occurs because of the poor capacity and skills in ICT management by people in charge of maintaining them within the organization. Therefore, these companies take too long to recover their investment and as they are not fully exploited, they tend to stop using them and consequently it becomes a cost for the organization that cannot be recovered.

With a correct implementation and referring to governance of the ICT's, these technologies can be used to the maximum and obtain a competitive advantage that would improve the organization's economic performance and recover the investment made more quickly.

Currently technology has become as a very important element within organizations, whether it is a public or private, so they invest a considerable amount in the acquisition, maintenance and development of the same. However, there is a difference with respect to the objectives that the organization presents, since the appropriate way of aligning the strategic objectives is sought and the so-called ICT government comes into play.

The technological infrastructure and internet access platforms are the foundations on which ICT's are based, since they allow access to services such as e-business and e-commerce, among others, they are also the ones that drive changes, reducing the gap that exists around the "Information Society" [1]. Therefore, ICT requires a significant investment, which affects $10.5 \%$ of revenues for some companies [2].

A series of drawbacks have been recognized, such 
as lack of vision regarding their current performance, infrastructure and personnel failures, data management, among others, as well as problems when internalizing the processes proposed in the model, such as achieving the alignment of strategies, risk management and development of value for the organization through its technology tools [3].

\section{A. ICT government}

Currently, the ICT Government, especially in companies, is spreading rapidly; half of the surveyed organizations acknowledge having implemented or are in the process of implementing elements of the ICT Government. In addition, the ICT Government is demonstrating its effectiveness and performance when it comes to obtaining the maximum value of ICT's for organizations, $65 \%$ of those responsible for ICT who have already implemented these systems recognize that they are effective [4].

To define more clearly, what corporate governance refers to, we will start with the explanation of the meaning of governance It is related to the way of governing and whose main objective is to obtain achievements that can be in different areas, such as economic, social and organizational.

It can be said that corporate governance is mainly related to management and control; however, the difference can be seen in the proposed structure, in which the distribution of the rights and responsibilities of each of the participants in the organization (general directory, managers, shareholders and others with an economic interest) stands out in the organization.

On the other hand, corporate governance can be defined as the set of principles and rules that regulate the design, integration and operation of the governing bodies of the organization, such as the three powers within an organization: Shareholders, Board of Directors and Senior Management [5].

Ross and Weill [6] mention that it is "an actively designed set of ICT governance mechanisms (for example, committees, budget processes, approvals, ICT organizational structure, charge back, etc.) that foster a behavior consistent with the mission, strategy, values, norms and culture of the organization". In addition, all this in order to get revenues for the organization.

The fact of having the implementation of ICT's; it does not represent itself a competitive advantage for organizations. It is the management of these technologies that can give an advantage to their success. According to what has been said, appropriating an ICT governance model for this management is a key element for the fulfillment of the organization's objectives [7].

In this part, it cannot be forgotten that that the development of clear policies and good practices for the security and control of ICT's is always important, in order to obtain the approval and support of the different levels of government of the organization [8]. In addition, this applies to the information systems of the entire organization, including personal computers and networks. It is based on the philosophy that ICT resources need to be managed by a set of naturally grouped processes to provide the pertinent and reliable information required by an organization to achieve its objectives. [9]

\section{B. ICT Governance}

Henriquez [2] mentions that the process of governance in this field consists of a structure of relationships and processes aimed to direct and control the organization, in order to achieve its objectives and add value while balancing the risks and returning investments on ICT's and its processes, (see Fig. 1).

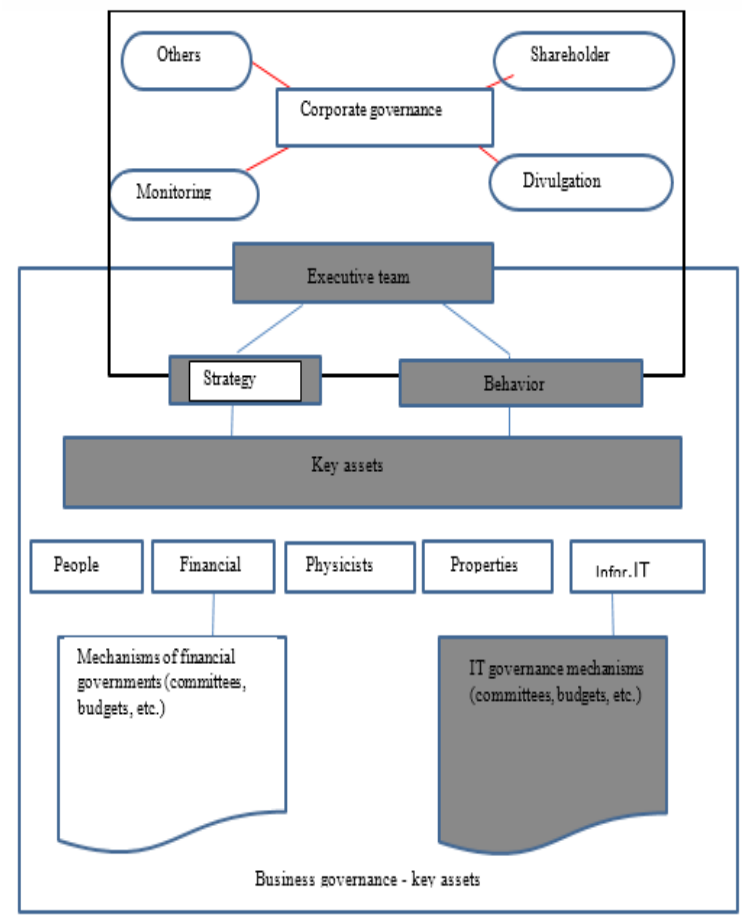

Fig. 1. ICT Governance. Adaptation of the model by Peter Weill and Jeanne W. Ross

Therefore, the governance of ICT's is a part of corporate governance, because of its structure in which decisions are made throughout its processes. It seeks to direct and control the operative part that oversees reaching the established goals, meeting the relevant objectives, adding value to the processes, and especially monitoring the returns that are obtained by ICT's.

ICT governance is the responsibility of executives and the board of directors, and consists of leadership, organizational structures and processes that ensure that the organization maintains and extends the organization's strategies and objectives [10]; The government of ICT is also defined as the structure by which the project's objectives are established, as well as it means to achieve them and to monitor the performance for them.

On the other hand, we must not forget that the ICT government puts into practice ensuring that the processes comply with the agreed standards, which will allow the organization to achieve the objectives that were proposed, obtain the information quickly and concisely, and to be able to take advantage of opportunities to gain an advantage over other competitors in the market.

It should also be emphasized that the ICT governance manages four fundamental principles that must be applied for a better performance of the government; these are: i) Direct and control, ii) Responsibility, iii) Accountability 
and iv) Activities [11].

From this premise we can complement another concept of what ICT governance is: who will be responsible for decision making and who will be responsible for the accounts of how ICT has been handled, who will be the one to say how ICT management should be leaded, how it has been benefiting and developing the organization, and how this has improved the individual and collective performance of internal collaborators. On the other hand, ICT government must be carried out the following areas: i) Strategic alignment, ii) Delivery of values iii) Risk management and iv) Performance measurement.

For a good performance of any tool, in this case the ICT which has an organization, can be analyzed from the point of view of an optimal investment, the allocation of adequate resources to meet the objectives set by the area of ICT, and the purpose of reducing costs that are related to this area.

\section{ICT Governance framework ISO/IEC 38500}

This framework can be found in the extensive literature of ICT's, each one has a particularity and its approaches are different, but at the same time, they are complementary due to the approaches. The Government Framework that uses ICT and which we are going to focus on is the ISO/IEC 38500 Corporate Governance of Information Technologies. This norm was based on its Australian pair AS8015: 2005, which is the first norm or standard on the governments of the ICT's (ISO/ IEC, 2008); Its objective is to provide a framework of principles on which organizations can base themselves to use when assessing, directing and monitoring the use of information technologies. This standard indicates six principles that form a base to create good corporate ICT governance: i) Responsibility (r): of individuals and groups; ii) Strategy (s): ICT satisfies the strategy of the organization; iii) Acquisition (a): of ICT for valid reasons; iv) Performance (p): based on supporting the business of the organization v) Fulfilment (f): with mandatory legislation and regulations and vi) Human behavior (h): response to the needs of all people in the process.

In this model, 3 areas were considered (evaluate, direct and control) as the main ones so that the roles that allow managing, planning, implementing and using ICT's can be addressed and controlled (see Fig. 2).

The model can be easily understood since the ICT government focus directly leads to the most basic business model: Plan - Build - Operate. It should be recognized that while this model is sometimes used by ICT specialists to explain aspects of the ICT cycle, it is also widely understood by business leaders and educators as the basic cycle of business management. That is the context in which it is used here [12].

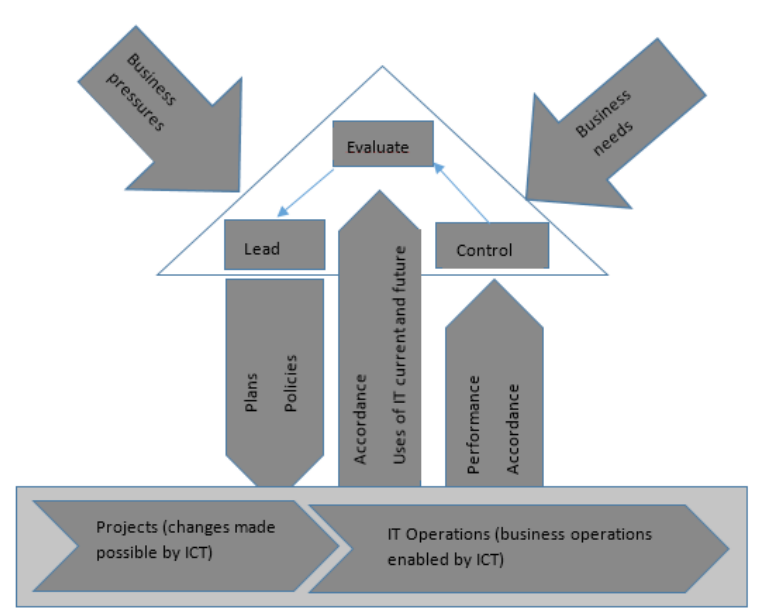

Fig. 2. Governance model IT ISO / IEC 38500

In addition, we should have clear overview at the time of choosing these technologies that will be those that provide us with some confidence when looking for effectiveness, efficiency, reliability, compliance, availability, integrity and confidentiality. Without forgetting that it is required to identify the types of resources or assets that the organization possesses, and the processes that are the necessary controls to be implemented for complying business requirements. The processes that are going to be implemented must be under supervision of the directives and executive management.

\section{MATERIALS AND METHODS}

\section{A. Nature of the investigation}

This research has a mixed approach (qualitative and quantitative). First, a state of art review in governance and technological management together with interviews with local experts in the sector were performed in order to get a contextualization for Ecuadorian organizations. Second, following Bosch [13] and Robalino-López and Aniscenko [14], 18 items for the six dimensions that ISO/IEC 38500 handles were used for the construction and validation of the tool. The scope of this research has a descriptive and exploratory character. In Ecuador, as far as we know, there are no studies about the ICT governance processes for commercial sector (Retail), being a completely new area for the region.

To fulfill the objectives of this study, we used a mixed design, and Non-Experimental - case of study, since no variable is going to be manipulated and only the facts and situations that interest this study will be observed. NonExperimental research was carried out in a cross-sectional manner since the facts that are currently happening in the organization, in the area of ICT's were observed. In addition, the current situation of the Ecuadorian retail sector was described and a tool ICT-staff, distributed as follows: i) 3 Operators or users, ii) for measuring governance processes was developed.

The Organization of the "case of study" has 9 people as 5 Middle controllers or key users and iv) 1 Director or leader.

ICT-staff of organization is described as: a professional with academic level of technical education, of third 
and fourth educational levels (bachelors and masters), belonging to the "Organization" in operative positions, middle managers and managers, with seniority in the position of at least one year in the organization.

\section{B. Research tools}

The research tools used in the present study were: i) Documentary research, ii) Interview and iii) Survey. Additionally, these tools were based on the activities suggested by the standard that is being handled, which in this case is ISO/IEC 38500, that is, both the survey and the interview that are based on the premises of this international standard.

The documentary research is defined as "the essential part of a scientific research process, contributing to a strategy where we observe and reflect systematically on realities using different types of documents for them [15]. The documentary research was made based on papers that manage the concepts of governance and how they focus on ICT, especially in the differentiation of corporate governance and business governance. It is also based on the principles of the ISO/IEC 38500 standard, which is what, is supported to give the guidelines for the governance of ICTs, and how these should be managed so that all the potential is used. The documentary research was carried out in order to lean about the state of art of the ICT Governance processes, focusing the study on the ISO 38500 standard, which was previously explained. The base texts for the development of the present study, in addition to all the complementary sources were [2], [16] - [19].

The interview is a fundamental tool that helps us to obtain information and allows to improve the knowledge of the processes by which the ICT governance can be established in the Ecuadorian retail sector, which works with marketing of mattresses. It also allowed us to have a better vision of the validation and contextualization of the survey to be developed [20]- [21].

The survey is an extremely important tool for research and in the case of this work it was essential because there was developed the questionnaire through which we focused on the retail sector of Ecuador. The survey was focused on the commercial sector of mattresses. The characteristics of the methodology to carry out the survey were: i) information sources collection: The primary source of information could be obtained in the area of Information Technology of the "Organization of the case of study", in which questions were organized in a survey, and it was done to the users, the supervisors and the leaders of ICT area of the organization. Totaling nine people corresponding to the organization-staff in the area of ICT's; ii) Composition of the survey: The instrument to validate was a questionnaire composed of contextual questions formulated in two stages that were designed to measure the previous state in which the implementation of the ICT's was carried out, taking into account the perception of the collaborators of the organization, and the importance that it had when the implementation or a subsequent analysis of it was carried out. For both questionnaires that were composed by 18 questions, the Likert scale from 0 to 3 points was taken as a measurement reference. The design and development of the tool forms an important part of the process in which the questionnaire was developed as an intermediate step; However, this only gave rise to the second stage from which the evaluation and adaptation of contents that should be in tune with the research of the work emerged; once this stage was finished, the validation of the tool was performed.

\section{Assessment method}

Following to Bin-Abbas and Bakry [22] and RobalinoLopez and Aniscenko [14], the proposed assessment method has two questions on each control element: the level of importance of the element (w[i]); and the level of its implementation $(\mathrm{g}[\mathrm{i}])$. Four levels were considered for both questions as illustrated in Table 1. Note that the two mentioned questions concerned with each issue can be assessed by ICT-staff of the organization (Operators or users, Middle controls or key users and Director or leader). Then it is important to find averages for not only the importance but also the implementation level, as shown in Table 1. In addition, a relative measure that combines the averages of both: importance and implementation can be found. This provides this relative combined measure as a percentage value (see Table 1).

TABLE 1. Assessment METHOD: IMPORTANCE (w[I]) AND IMPLEMENTATION LEVEL (g[i]).

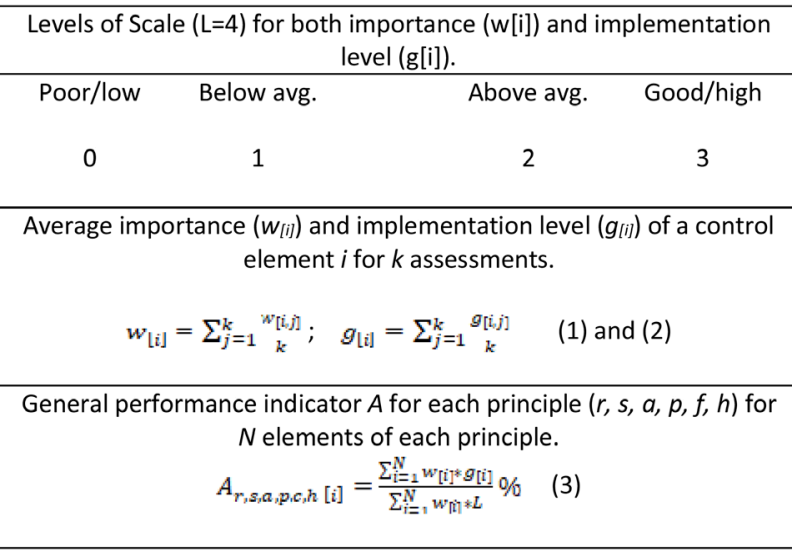

General performance indicator $A_{t}$ : for $N_{t}$ elements of the model.

$$
A t_{[i]}=\frac{\sum_{i=1}^{N_{t}} w_{[i]} * g_{[i]}}{\sum_{i=1}^{N_{t}} w_{[i]} * L} \%
$$

The mentioned above can be applied both to the basic ICT governance control elements mentioned in the standard and to other possible elements that may be needed for specific cases (organizational field characteristics). As will be shown below, the ICT governance's requirement controls are open to further additional considerations that may be considered. This enhances knowledge sharing and support improvement. 
excellence and competitiveness of organizations.

The assessment of compliance with the six principles

\begin{tabular}{|c|c|c|c|}
\hline & EVALUATE & LEAD & CONTROL \\
\hline 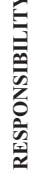 & $\begin{array}{l}\text { (RE1) The models and } \\
\text { options for assigning } \\
\text { responsibilities. } \\
\text { (RE2) The competences } \\
\text { of those who receive } \\
\text { responsibility. }\end{array}$ & $\begin{array}{l}\text { (RL1) That the designed } \\
\text { plans are carry out. } \\
\text { (RL2) Those managers } \\
\text { receive the information } \\
\text { they need to make } \\
\text { decisions. }\end{array}$ & $\begin{array}{l}\text { (RC1) The assignment of } \\
\text { responsibilities. } \\
\text { (RC2) The adequate } \\
\text { performance of assigned } \\
\text { responsibilities (indicators). }\end{array}$ \\
\hline & $\begin{array}{l}\text { (SE3) Development of } \\
\text { ICT to verify that they will } \\
\text { support the business in the } \\
\text { future. } \\
\text { (SE4) Alignment of ICT } \\
\text { activities with business } \\
\text { objectives. } \\
\text { (SE5) Management of risks } \\
\text { related to the use of ICT. } \\
\end{array}$ & $\begin{array}{l}\text { (SL3) Design policies and } \\
\text { plans that take advantage } \\
\text { of the value of ICT. } \\
\text { (SL4) ICT Innovation. }\end{array}$ & $\begin{array}{l}\text { (SC3) The objectives are } \\
\text { meet in the term with the } \\
\text { planned resources. } \\
\text { (SC4) The results to verify } \\
\text { that the expected benefits } \\
\text { have been achieve. }\end{array}$ \\
\hline 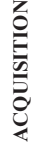 & $\begin{array}{l}\text { (AEG) Different options } \\
\text { with ICT offers in relation } \\
\text { to cost and risk. Risk / value } \\
\text { analysis. }\end{array}$ & $\begin{array}{l}\text { (AL5) The asset purchase } \\
\text { procedure is carrying out } \\
\text { appropriately. } \\
\text { (AL6) Meeting the needs } \\
\text { of the organization. }\end{array}$ & $\begin{array}{l}\text { (AC5) Investments provide } \\
\text { the expected capabilities. } \\
\text { (AC6) The internal / external } \\
\text { understanding needs the } \\
\text { organization. }\end{array}$ \\
\hline & $\begin{array}{l}\text { (PE7) Operational proposals } \\
\text { from ICT managers to } \\
\text { maintain business capacity. } \\
\text { (PE8) The risk of ICT in } \\
\text { relation to the continuity of } \\
\text { business operations. } \\
\text { (PE9) The risk of the } \\
\text { integrity of information and } \\
\text { the protection of assets. } \\
\text { (NE10) The effectiveness of } \\
\text { ICT decisions in support of } \\
\text { the organization }\end{array}$ & $\begin{array}{l}\text { (PL7) Those enough ICT } \\
\text { resources are available. } \\
\text { (PL8) That the correct } \\
\text { and updated information } \\
\text { is providing to the } \\
\text { management as support for } \\
\text { the decisions. } \\
\text { (PL9) Assign priorities } \\
\text { and restrictions. }\end{array}$ & $\begin{array}{l}\text { (PC7) To what extent ICT } \\
\text { support the business. } \\
\text { (oP8) The priorititation } \\
\text { of resource allocation } \\
\text { in relation to business } \\
\text { objectives. } \\
\text { (PC9) Compliance with } \\
\text { established policies and rules } \\
\text { (PC10) Data accuracy } \\
\text { policies and efficient use } \\
\text { of ICT. }\end{array}$ \\
\hline 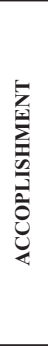 & $\begin{array}{l}\text { (AE11) To what extent are } \\
\text { the guidelines, legislation } \\
\text { and internal rules establish. } \\
\text { (AE12) Compliance } \\
\text { with internal procedures } \\
\text { established in the } \\
\text { organization. }\end{array}$ & $\begin{array}{l}\text { (AL10) Those mechanisms } \\
\text { be establishing to verify } \\
\text { compliance with laws, } \\
\text { standards and standards. } \\
\text { (AL1) Those policies be } \\
\text { establishing that support } \\
\text { the use and integration } \\
\text { of ICT. } \\
\text { (AL12) That the ICT } \\
\text { personnel have a } \\
\text { professional behavior and } \\
\text { respect the procedures. } \\
\text { (AL13) That an ethical use } \\
\text { of ICT be make. }\end{array}$ & $\begin{array}{l}\text { (AC11) Compliance and } \\
\text { compliance (audits / reports). } \\
\text { Timely, complete and } \\
\text { adequate. } \\
\text { (AC12) ICTs preserve } \\
\text { privacy and strategic } \\
\text { knowledge. } \\
\text { (AC13) ICT processes. }\end{array}$ \\
\hline 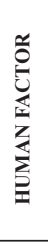 & $\begin{array}{l}\text { (FE13) That the human } \\
\text { component is identify and } \\
\text { take into account in all ICT } \\
\text { activities. }\end{array}$ & $\begin{array}{l}\text { FL14) Those ICT } \\
\text { activities are consistent } \\
\text { with the human } \\
\text { component. } \\
\text { (FL15) The risks and } \\
\text { opportunities can be } \\
\text { identified and reported } \\
\text { (policies and procedures) } \\
\text { to the directors for their } \\
\text { evaluation }\end{array}$ & $\begin{array}{l}\text { FC14) The perception of } \\
\text { the importance of the human } \\
\text { component (training). } \\
\text { FC15) The application } \\
\text { of appropriate practices to } \\
\text { be consistent with the use } \\
\text { of ICT }\end{array}$ \\
\hline
\end{tabular}
of the ISO/IEC 38500 standard will be based on the recommendations of good ICT governance made by Bosch [13]: i) It is addressed to top management, as it indicates the way in which they should evaluate, direct and monitor the use of ICT's throughout the organization. ii) But it is also an aim at ICT managers, as it informs and guides them on how to design and implement management policies, processes and structures that support ICT governance. Managers should govern ICTs through the actions of Evaluating, Directing and Monitoring, following the model proposed by ISO 38500 [13]. Monitor, through an adequate measurement system, the appropriate policies, extremely clear procedures and established plans "Table 2".

\section{B. Results of the evaluation}

The evaluation carried out, in which the surveys were used, was developed according to the frame of reference of the ISO/IEC 38500 standard. In addition, the evaluation of the information obtained from secondary and primary sources was made, from which we took the relevant information and transformed it into annotations or citations that helped us to mark the development of this study.

Through survey, conducted results were obtained with which we can assess ICT infrastructure, whether the staff agrees or disagrees with the management of ICT's in the organization and on premise with the principles based on ISO / IEC 38500.

Table 3 shows the answers of all the principles related to the questions posed in the survey. In this part, we will analyze the percentage of compliance that the organization has in relation to the two dimensions (Implementation and Importance) that were raised in the query.

In Fig. 3, we can see that the compliance percentages are high, but if we refer to those that pass $80 \%$ we can see that the questions of the principle of responsibility, the three surpass this percentage (see Table 3 ).

In the principle of strategy, two questions surpass; in the principle of acquisition, performance and compliance only one question exceeds or equals this percentage; while the principle of human factor none of the three questions reaches the minimum established.

Similarly, when analyzing Table 4 (compliance percentage, importance dimension), we can observe that compliance percentages are high, but if we refer to those that pass or are to equal $80 \%$, we can see that the questions of the strategy principle and human factor, all three indicators that surpass this percentage.

In the principle of responsibility, performance and compliance, two questions exceed the percentage, while in the principle of acquisition none of the three questions reaches the minimum established. 
Robalino-López et al. A Methodology to Diagnose ICT Governance Process Based on ISO/IEC 38500 Standard. Case Study: Ecuadorian Retail Organization

Table 3. Perception of compliance Implementation

\begin{tabular}{|c|c|c|c|}
\hline \multicolumn{4}{|c|}{ Perception of compliance Implementation } \\
\hline Question & Principle & Score & $\%$ compliance \\
\hline $\mathrm{P} 1$ & Responsibility & 32 & 80,00 \\
\hline $\mathrm{P} 2$ & Responsibility & 34 & 85,00 \\
\hline P3 & Responsibility & 33 & 82,50 \\
\hline & & Average & 82,50 \\
\hline
\end{tabular}

\begin{tabular}{|c|c|r|r|}
\hline Question & Principle & Score & $\%$ compliance \\
\hline P4 & Strategy & 34 & 85,00 \\
\hline P5 & Strategy & 30 & 75,00 \\
\hline P6 & Strategy & 35 & 87,50 \\
\hline
\end{tabular}

\begin{tabular}{|c|c|r|r|}
\hline Question & Principle & \multicolumn{1}{|c|}{ Score } & \% compliance \\
\hline P7 & Acquisition & 33 & 82,50 \\
\hline P8 & Acquisition & 31 & 77,50 \\
\hline P9 & Acquisition & 30 & 75,00 \\
\hline
\end{tabular}

\begin{tabular}{|c|c|r|r|}
\hline Question & Principle & Score & $\%$ compliance \\
\hline P10 & Performance & 29 & 72,50 \\
\hline P11 & Performance & 30 & 75,00 \\
\hline P12 & Performance & 32 & 80,00 \\
\hline \multicolumn{2}{l}{} & Average & $\mathbf{7 5 , 8 3}$ \\
\cline { 2 - 4 }
\end{tabular}

\begin{tabular}{|c|c|r|r|}
\hline Question & Principle & \multicolumn{1}{|c|}{ Score } & $\%$ compliance \\
\hline P13 & Accomplishment & 29 & 72,50 \\
\hline P14 & Accomplishment & 30 & 75,00 \\
\hline P15 & Accomplishment & 35 & 87,50 \\
\cline { 2 - 4 } & Average & $\mathbf{7 8 , 3 3}$ \\
\hline
\end{tabular}

\begin{tabular}{|c|c|r|r|}
\hline Question & Principle & Score & $\%$ compliance \\
\hline P16 & Human factor & 30 & 75,00 \\
\hline P17 & Human factor & 30 & 75,00 \\
\hline P18 & Human factor & 31 & 77,50 \\
\hline & & Average & $\mathbf{7 5 , 8 3}$ \\
\hline
\end{tabular}

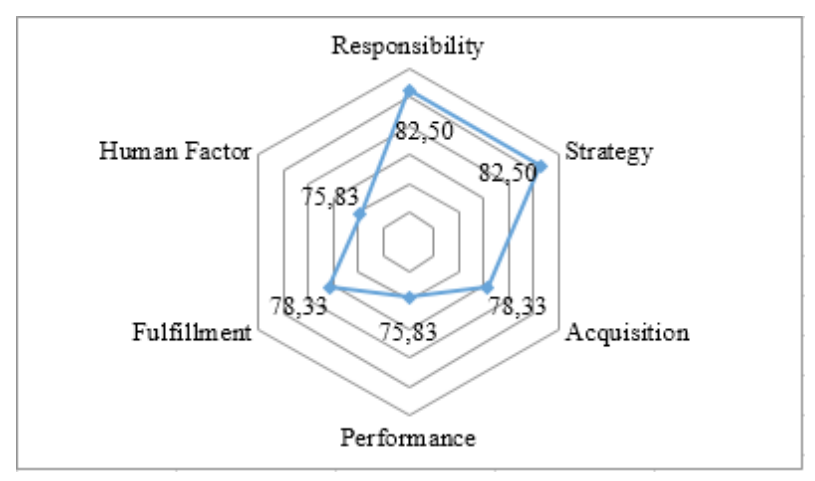

Fig. 3 Perception of compliance Implementation

Results obtained have a direct relationship with respect to the definitions made by the international standard ISO / IEC 38500. With the survey, conducted results were obtained with which we can assess whether the staff agrees or disagrees with the management of ICTs in the organization and on premise with the principles based on ISO/IEC 38500.

Table 4. Perception of compliance Importance

\begin{tabular}{|c|c|c|c|}
\hline \multicolumn{4}{|c|}{ Perception of compliance Importance } \\
\hline Question & Principle & Score & \% compliance \\
\hline P1 & Responsibility & 33 & 82,50 \\
\hline P2 & Responsibility & 30 & 75,00 \\
\hline P3 & Responsibility & 34 & 85,00 \\
\hline \multirow{2}{*}{} & Average & 80,83 \\
\cline { 3 - 4 }
\end{tabular}

\begin{tabular}{|l|l|r|r|}
\hline Question & Principle & \multicolumn{1}{l|}{ Score } & \% compliance \\
\hline P4 & Strategy & 34 & 85,00 \\
\hline P5 & Strategy & 32 & 80,00 \\
\hline P6 & Strategy & 33 & 82,50 \\
\hline \multicolumn{2}{|r}{} & Average & $\mathbf{8 2 , 5 0}$ \\
\cline { 2 - 4 }
\end{tabular}

\begin{tabular}{|l|l|r|r|}
\hline Question & Principle & \multicolumn{1}{l|}{ Score } & \% compliance \\
\hline P7 & Acquisition & 31 & 77,50 \\
\hline P8 & Acquisition & 31 & 77,50 \\
\hline P9 & Acquisition & 30 & 75,00 \\
\hline \multicolumn{2}{|l}{} & Average & $\mathbf{7 6 , 6 7}$ \\
\cline { 3 - 4 }
\end{tabular}

\begin{tabular}{|c|c|c|c|}
\hline Question & Principle & Score & $\%$ compliance \\
\hline P10 & Performance & 34 & 85,00 \\
\hline P11 & Performance & 31 & 77,50 \\
\hline $\mathrm{P} 12$ & Performance & 33 & 82,50 \\
\hline & & Average & 81,67 \\
\hline
\end{tabular}

\begin{tabular}{|c|c|c|c|}
\hline Question & Principle & Score & $\%$ compliance \\
\hline P13 & Accomplishment & 33 & 82,50 \\
\hline P14 & Accomplishment & 30 & 75,00 \\
\hline $\mathrm{P} 15$ & Accomplishment & 34 & 85,00 \\
\hline & & Average & 80,83 \\
\hline
\end{tabular}

\begin{tabular}{|l|l|r|r|}
\hline Question & Principle & \multicolumn{1}{l|}{ Score } & \% compliance \\
\hline P16 & Human factor & 32 & 80,00 \\
\hline P17 & Human factor & 32 & 80,00 \\
\hline P18 & Human factor & 33 & 82,50 \\
\hline \multicolumn{2}{l}{} & Average & $\mathbf{8 0 , 8 3}$ \\
\cline { 2 - 4 }
\end{tabular}

Similarly, when analyzing Fig. 3 (compliance percentage, implementation dimension), we can see that the compliance percentages are high, but if we refer to those that pass $80 \%$ we can see that the questions of the principle of responsibility, the three surpass this percentage; In the principle of strategy, two questions surpass this percentage; in the principle of acquisition, performance and compliance only one question exceeds or equals this percentage; while the principle of human factor none of the three questions reaches the minimum established.

In Fig. 4 (compliance percentage, importance 
dimension), we can observe that compliance percentages are high, but if we refer to those that surpass or are equal to $80 \%$, we can see that the questions of the strategy principle and human factor, all three surpass this percentage.

In the principle of responsibility, performance and compliance, two questions exceed the percentage, while in the principle of acquisition none of the three questions reaches the minimum established.

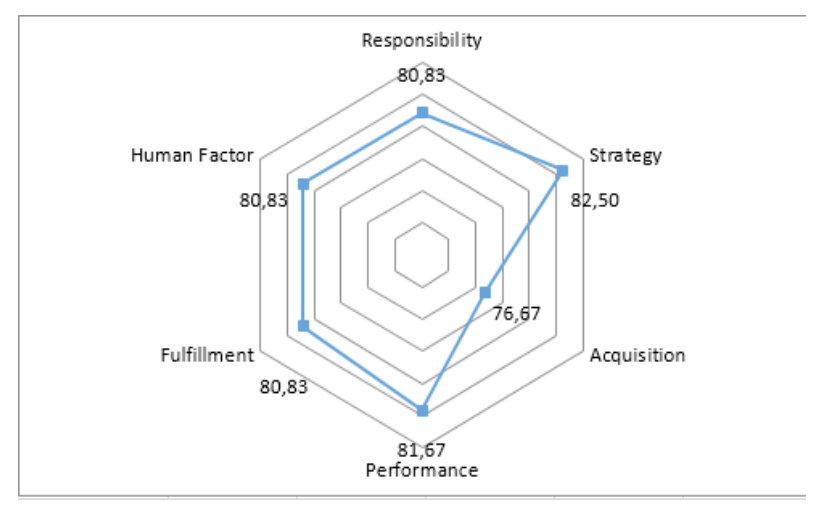

Fig. 4 Perception of compliance Importance

\section{CONCLUSIONS}

The study proposes the use of new methodology approach to analyze the governance processes of ICTs within organizations. The approach is showing in a case study of the organization in the Ecuadorian retail sector.

The aim is to use the ISO/IEC 38500 model as a basis in conjunction with an adhoc model (Bosch model) to have a broader vision of the processes involving ICTs in Ecuadorian retail companies. Indicators that were generated allowed to obtain a first diagnosis of the use of ICTs within the organization and show the implementation of the proposed approach.

The design of the tool for the collection of information is based mainly on the proposed model. This model was developed to obtain a broader perspective of how the ISO/ IEC 38500 standard should be evaluated and implemented within organizations. The tasks in the management process: assess, direct and control are fundamental to understand the good use of the ICT resource within the organization.

The diagnosis made in the organization of the case study shows the use of an important amount of resources, (human and economic) within the area of technologies; However, there are considerable gaps in the implementation and import perspectives in the model: This reveals that there is a gap between the real state of the processes and their ideal state. The results provide a wider and more useful view for the top management of the organization.

\section{ACKNOWLEDGEMENTS}

This work has been funded by Escuela Politécnica Nacional of Ecuador, under the Research Projects PIJ-1610 and PIMI-16-02.

\section{REFERENCES}

[1] S. Cedeño and A. Robalino, "Rediseño de la infraestructura del proveedor de servicios de internet ONNET SA para la optimización del servicio en el Distrito Metropolitano de Quito," Tesis, Escuela Politecnica Nacional del Ecuador, Quito, Ecuador, 2008.

[2] S. Henriquez, "Implantación de Gobierno TI. NETWORK-SEC," 2011.

[3] A. I. Almanza Gomez, "La aplicación de Cobit en las organizaciones ¿vale la pena el esfuerzo?,” Tesis, Universidad Militar Nueva Granada, 2012.

[4] A. Fernández Martinez and F. Llorens Largo, "Gobierno de las TI en las Universidades Españolas,” Univ. Almer., 2011.

[5] R. Salvochea, "Mercados y buen gobierno corporativo. Buenos Aires: La Ley.," 2012. [Online]. Available: https:// WWW.virtuniversidad.com/greenstone/collect/ administracion/archives/HASH2cad.dir/doc.pdf. [Accessed: 10-Feb-2016]

[6] J. W. Ross and P. Weill, "IT Goverance: How Top Performers Manage IT Decisions Rights for Superior Results," IT Goverance How Top Performers Manag. IT Decis. Rights Super. Results, no. Issue: Harvard Business School Press Boston, Massachusetts, Pages: 1-10, pp. 1-13, 2004.

[7] C. E. Marulanda Ecehevrry, M. López Trujillo, and C. A. Cuesta Iglesias, "Modelos de Desarrollo para Gobierno TI. Models of development for IT government," Sci. Tech., vol. 1, no. 41, pp. 185-190, 2009.

[8] N. E. O. E. P. Fitzgerald, “Cobit," 2009. [Online]. Available: https://www.slideshare.net/nikifitz/cobit-1154456. [Accessed: 10-Feb-2016].

[9] J. Ocrospoma, "Investigación Cobit," 2014. [Online]. Available: http://cobitcbt.blogspot.com/. [Accessed: 16-Feb-2016].

[10] R. Moeller, Sarbanes-Oxley internal controls effective auditing with AS5, CobiT and ITIL, John Wiley. Hoboken: John Wiley \& Sons, Inc., 2008.

[11] ITGI, "Global Status Report on the Governance of Enterprise It ( GEIt ) - 2011,” Gov. An Int. J. Policy Adm., p. 70, 2011.

[12] M. Toomey, "Waltzing with the Elephant: (Bailando el Vals con el Elefante)," pp. 1-59, 2016.

[13] A. Bosch Pujol, "Herramientas para la implantación del gobierno de las TI: ISO 38500," p. 12, 2008.

[14] A. Robalino-López amd Z. Aniscenko, Gap analysis of ICT governance in organizations: A simple implementation approach since ISO/IEC 38500, Cladea Annual Conference Proceedings, 2015.

[15] P. Bravo, Luis; Ramirez, Tulio; Mendez, La Investigación documental y bibliográfica, Panapo. Caracas: Panapo, 1987.

[16] I. L. Muñoz Periñán and G. Ulloa Villegas, "Gobierno de TI Estado del arte,” Sist. Telemática, vol. 9, pp. 23-53, 2011.

[17] A.; F. L. L. Fernández Martinez, "Gobierno de las TI para universidades," 2007, vol. 136, no. 1, pp. 23-42.

[18] Z. Aniscenko, A. Robalino-López, T. E. Rodríguez, \& B. E. Pérez. "Regional cooperation in dealing with environmental protection. E-government and sustainable development in andean countries". The Vide. Tehnologija. Resursi - Environment, Technology, Resources, 1 13-19. 2017. https://doi.org/.17770/ etr2017vol1.2578

[19] A. Robalino-López, V. Ramos, X. Unda, J.L. Román, "Gestión empresarial y análisis de ventajas competitivas. Portafolio de negocio de las telefónicas en Ecuador," Revista CienciAmérica 6 (3), 17-22. 2017.

[20] A Robalino-López, V Ramos, X Unda and A Franco, University's contribution to industries in the creation of a tool to diagnose innovation management processes. INTED 2017 Proceedings, 2351-2360, 2017.

[21] A Robalino-López, V Morales, X Unda, Z Aniscenco. "Procesos de desarrollo e innovación: aplicación de una metodológica para medir el nivel de innovación en el contexto organizacional ecuatoriano" Brazilian Journal of Development, vol. 5, pp. 45504567, Apr. 2019.

[22] H. Bin-Abbas and S. H. Bakry. "Assessment of IT governance in organizations: A simple integrated Approach". Computers in Human Behavior 32, p. 261-267, 2014. 